\section{MODERN PSYCHIATRY IN PRACTICE}

By W. Lindsay Neustatter, M.D., M.R.C.P., B.Sc. Consulting Psychiatrist to the London County Council School Health Service; Physician in charge of Psychological Medicire, Queen Mary's Hospital for the East End, the Royal Hampshire County Hospital, Winchester, and the Royal South Hants Hospital, Southamptor. 2nd Edition. J. and A. Churchill Ltd. 1948. Pp. 274. Price r2s. 6d.

This is a readable book which avoids the pitfall so often descended by the authors of new textbooks both short and long-that of repeating the traditional descriptions and time-honoured oninions in slightly altered language. It is writter primarily for the general medical practitioner and the student, and in it they will find a good deal of sound psychiatric sense. The style is extremely vigorous, at times racy, and the author's meaning is never obscure. It is to be hoped that those who receive their introduction to psychiatry through this effervescent cocktail will not be spoiled for the more serious and arid reading necessary for a solid knowledge of the subject. The scope of the book is very wide and it is inevitable that some important subjects should be summarily dealt with. The chapters on psychopathy (psychopathic personality) and organic disorders are too brief to convey a true impression of the importance of these conditions, while general psychopathology is dismissed in I $2:$ pages. On the other hand, one-fifth of the book is devoted to psychiatric disorders in children and there is a useful chapter on the law and some problems of disposal.

W.P.M.

\section{SEXUAL ENDOCRINOLOGY OF NON- MAMMALIAN VERTEBRATES}

By L. H. Bretschneider and J. J. Duyvene de Wit. Elsevier Publishing Co. I 947. Price I5s.

The bitterling is a freshwater fish that lays its eggs inside the shells of living mussels. In order to do this the female develops, at spawning time, a long tubular ovipositor; this shrinks, during the rest of the year, to a hardly visible nipple. It was found, in I934, that the ovipositor can be made to grow at any time of the year if various sex hormones, including oestrone, oestradiol and progesterone, are added to the water in which the fish are living.

This book is an account of work done in Holland during the war in extension and analysis of this promising discovery. First they devised a method of using the 'ovipositor test' for endocrinological assays. The solution under investigation is added to the tank water; the ovipositor of a number of fish is measured at intervals, and a growth curve is plotted. The authors claim that many hormones can be identified by the form of the growth curve they produce under defined conditions. The test has the advantage that it can be completed in from two to three days, and that the test animals can be used repeatedly.
Evidence is produced to show that the hormones are absorbed into the fishes' blood system through the gills, and affect the reproductive system by way of the pituitary. There is a detailed study of the organization of the sexual-endocrine system of this and other fish, and of amphibia; this contains an abundance of useful information. The authors excuse themselves from general reference to the literature on the grounds that the work was done in isolation; hence their results are not put in their proper context, and there is no attempt at bibliographical completeness. The book is in paper covers, but is otherwise well-produced.

W.H.

\section{THE DIGESTIVE TRAGT IN ROENTGENOLOGY}

By Jacob Buchstein, M.D. Pp. xvi and 889. I,०30 illustrations. J. B. Lippincott Co. 1948. f5.

To those who are acquainted with the author's past work on the gastro-intestinal tract, the appearance of this volume as a new book may be a little confusing. Buchstein has chosen to present this under the above title rather than to produce a revised edition of his book of 1940 , the title of which was Clinical Roentgenology of the Alimentary Tract.

In effect, however, this is a revised and enlarged version of the former work, a fact which does not stand to the demerit of this presenc book, but which rather will commend it to all who have read with pleasure and profit the wealth of material contained in the former.

This present volume is a complete and comprehensive radiological study of the gastro-intestinal tract. It carries on the torch that was lit by Barclay in his classic monograph of ryro.

Starting with the hypo-pharynx and working in logical sequence through the gut, the normal and pathological appearances of the barium meal are described and illustrated. The author from a quarter of a century of experience has been able to draw upon his own cases for a large proportion of the material presented and the frequent case reports, with surgical or post-mortem findings, stamp with authority the descriptions and discussion of the radiological appearances.

Very ample references are given at the end of each section, although it seems to the writer that the German and American literature has perhaps been given undue emphasis.

The author sensibly refrains from treating the rare lesion at undue length at the expense of the everyday condition and devotes considerable space to such an important part of gastro-intestinal radiology as the significance of the variations in appearance of the duodenal cap. One might criticize, however, his treatment of duodenitis as a little perfunctory while contributions to the literature made in this country are ignored.

The small intestine is treated in this book more fully than formerly and includes the modern work 